\title{
A Family with Heritable Electrocardiographic QT-prolongation
}

\author{
P. J. C. VAN DER STRAATEN and C. L. D. BRUINS \\ Department of Paediatric Cardiology, Paediatric Department, Leiden University Hospital, The Netherlands
}

Summary. A report is presented concerning a family with heritable electrocardiographic QT-prolongation attacks of syncope and possible sudden death. In 23 family members investigated, nine living cases were found to have the anomaly. Of these nine patients at least two had had syncopes in early childhood. Hearing loss was found in three of the nine patients, but in one of them this could have been due to noise trauma and in another hearing loss was unilateral. The inheritance follows an autosomal dominant pattern. As far as we know this is the first report of this disease from The Netherlands.

In 1967, Ward reported a family in which some members suffered from a new disease that he called familial cardiac arrhythmia. He described two sibs with unexplained attacks of loss of consciousness. On investigation they had distinct electrocardiographic abnormalities. There was prolongation of the QT-interval and the aspect of the ST segment was very abnormal. Abnormal electrocardiograms were recorded in 10 of 28 family members. The inheritance followed an autosomal dominant pattern. We describe here another family with the disease.

\section{Method of Investigation}

After ascertainment of the propositus, his parents and three brothers were also investigated. The investigation consisted of physical examination, electrocardiogram, phonocardiogram, chest radiology, audiometric testing, and measurement of serum $\mathrm{Ca}, \mathrm{K}, \mathrm{Mg}, \mathrm{SGOT}$, $\mathrm{LDH}, \mathrm{CPK}$, and aldolase. Because the father and two brothers had the same ECG-abnormalities, the sibs of the father and their children were also examined. In these the programme was restricted to physical examination, ECG, and audiometric testing. The QT- and RRintervals were read in lead II, the mean value of four consecutive complexes was taken. For calculation of the normal value of QT-time the regression formula of Fraser, Frogatt, and James (1964) was used:

$$
\mathrm{QT}_{\mathrm{c}}=\mathrm{a}+\mathrm{b}(\mathrm{RR})+\mathrm{c}\left(\mathrm{R}^{2}\right)+\mathrm{d} \text { (age). }
$$

A prolongation of $\mathrm{QT}$-time with more than 0.04 seconds was considered as abnormal.

Received 27 October 1972.

\section{Results}

The propositus, III.5, was seen at the age of 10 years in our department because of frequent syncope and because he tired easily. On admission he had a slow regular pulse and the blood pressure was normal. The heart was of normal size. The electrocardiogram showed prolongation of the QTinterval: $0 \cdot 60$ seconds while it should have been $0 \cdot 38$ seconds. The $T$-wave was biphasic in $V_{1}-V_{4}$ and positive in $V_{5}$ and $V_{6}$. Chest radiology and the phonocardiogram were normal. With audiometric testing only a slight hearing loss was recorded of $\pm 20 \mathrm{db}$ in low frequencies until $500 \mathrm{~Hz}$ and a loss of $\pm 20 \mathrm{db}$ from 1500 to $3000 \mathrm{~Hz}$. The hearing loss was of the perceptive type. The values for $\mathrm{Ca}, \mathrm{K}$, $\mathrm{Mg}$, SGOT, LDH, CPK, and aldolase were normal for the propositus, his parents and his three brothers. The electrocardiograms of his father (II.2) and two brothers (III.4 and III.6) were abnormal. The audiometric testing of II.2 and III.4 also demonstrated a loss of hearing. The father had a hearing loss of up to $50 \mathrm{db}$, in the high frequencies, but this could have been caused by his working in a factory. One brother (III.4) had some mild hearing loss of $\pm 30 \mathrm{db}$ in the frequency of $4000 \mathrm{~Hz}$ but only in the left ear.

The investigation of the five sibs of the father with their children gave the following results. In 18 family members five abnormal electrocardiograms were recorded. One sister of the father (II.3), three 


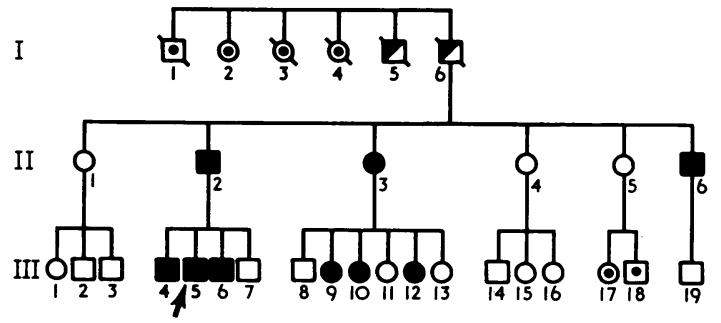

$\begin{aligned} \square O & =\text { Not investigated } \\ & =\text { Abnormal ECG } \\ & =\text { Sudden unexpected deoth ot early age } \\ \square Q & =\text { Deceased }\end{aligned}$

FIG. 1. Family pedigree.

of her six children (III.9, III.10, and III.12), and one brother (II.6) had a prolonged QT-interval. The girl (III.9) is the only one who suffered from syncope attacks at the age of 3 years; she is now without complaints at the age of 17 years.

No history of syncopes in childhood was obtained from the father, his sister, or his brother. The audiometric testing was normal in the families of II.3, II.4, and II.6 and in II.5. The grandfather (I.6) and his brother (I.5) died suddenly and unexpectedly at the ages of 39 and 29 years. The cause of death could not be ascertained.

The ECG data are summarized in Table I and the family tree is shown in Fig. 1.

\section{Discussion}

In this family with heritable electrocardiographic QT-prolongation nine of 23 members showed a prolongation of the QT-interval. Probably only two of these nine suffered from syncope at an early age. They have now been without symptoms for 5 and 13 years, respectively, after the syncopal attacks. The sudden unexpected deaths of the paternal grandfather (I.6) and his brother (I.5) are suggestive of the same disease. Only three of the nine patients had a mild hearing loss of the perception type. In one of these three this could have been due to noise damage; in another the hearing loss was limited to one ear.

The cause of the heart disease is not yet clear. In contrast with the syndrome of Jervell and LangeNielsen (1957) the atrioventricular node artery is normal. The myocardium and conducting tissue have a normal histology (Ward, 1967). Probably the disturbance of repolarization is caused by a biochemical disorder at the cellular level (Fraser et al, 1964). The syncope attacks are caused by ventricular fibrillation. Syncopes in infancy or childhood followed by a symptom-free interval of many years were found by various authors (Fraser et al, 1964; Garza et al, 1970). Although the QT-interval is shortened and the $\mathrm{T}$-wave acquires a more normal aspect with digitalis, syncope, and sudden death have also been observed under digitalis therapy. Our patients were not treated with digitalis.

TABLE I

ECG INVESTIGATIONS

\begin{tabular}{|c|c|c|c|c|c|c|c|}
\hline Case & $\begin{array}{l}\text { Age } \\
(\mathrm{yr})\end{array}$ & Sex & $\mathrm{RR}(\mathrm{sec})$ & QT (sec) & $\mathrm{QT}_{\mathrm{c}}(\mathrm{sec})$ & $\begin{array}{c}\text { Prolonged } \\
\text { QT }\end{array}$ & $\begin{array}{c}\text { Syncopal } \\
\text { Attacks }\end{array}$ \\
\hline $\begin{array}{l}\text { III.1 } \\
\text { III. } 1 \\
\text { IIII. } 2 \\
\text { III } .3\end{array}$ & $\begin{array}{l}50 \\
27 \\
23 \\
19\end{array}$ & $\begin{array}{l}F \\
F \\
M \\
M\end{array}$ & $\begin{array}{l}0.84 \\
0.70 \\
0.91 \\
0.98\end{array}$ & $\begin{array}{l}0.35 \\
0.36 \\
0.36 \\
0.41\end{array}$ & $\begin{array}{l}0.35 \\
0.35 \\
0.39 \\
0.38\end{array}$ & E & E \\
\hline $\begin{array}{l}\text { III.2 } \\
\text { III. } 4 \\
\text { III } 5 \\
\text { III. } 6 \\
\text { IIII. } 7\end{array}$ & $\begin{array}{r}45 \\
18 \\
14 \\
12 \\
6\end{array}$ & $\begin{array}{l}M \\
M \\
M \\
M \\
M\end{array}$ & $\begin{array}{l}1.56 \\
1.07 \\
1.26 \\
0.85 \\
0.52\end{array}$ & $\begin{array}{l}0.62 \\
0.45 \\
0.60 \\
0.42 \\
0.29\end{array}$ & $\begin{array}{l}0.34 \\
0.40 \\
0.38 \\
0.37 \\
0.29\end{array}$ & $\begin{array}{l}\times \\
x \\
\times \\
\times \\
\end{array}$ & $\frac{-}{x}$ \\
\hline $\begin{array}{l}\text { II. } 3 \\
\text { III.8 } \\
\text { III.9 } \\
\text { III.10 } \\
\text { III.11 } \\
\text { III.12 } \\
\text { III.13 }\end{array}$ & $\begin{array}{r}44 \\
19 \\
17 \\
12 \\
10 \\
5 \\
1\end{array}$ & $\begin{array}{l}F \\
M \\
F \\
F \\
F \\
F \\
F\end{array}$ & $\begin{array}{l}0.98 \\
1.38 \\
0.78 \\
0.93 \\
1.06 \\
0.91 \\
0.36\end{array}$ & $\begin{array}{l}0.46 \\
0.41 \\
0.42 \\
0.43 \\
0.38 \\
0.42 \\
0.21\end{array}$ & $\begin{array}{l}0.38 \\
0.41 \\
0.36 \\
0.38 \\
0.37 \\
0.36 \\
0.24\end{array}$ & $\begin{array}{l}\frac{x}{x} \\
\frac{x}{x} \\
\end{array}$ & $\begin{array}{l}\text { E } \\
\overline{-} \\
=\end{array}$ \\
\hline $\begin{array}{l}\text { II. } 4 \\
\text { III. } 14 \\
\text { III.15 } \\
\text { III. } 16\end{array}$ & $\begin{array}{r}39 \\
11 \\
9 \\
1\end{array}$ & $\begin{array}{l}F \\
M \\
F \\
F\end{array}$ & $\begin{array}{l}0.84 \\
0.72 \\
0.76 \\
0.54\end{array}$ & $\begin{array}{l}0.35 \\
0.33 \\
0.34 \\
0.29\end{array}$ & $\begin{array}{l}0.35 \\
0.33 \\
0.35 \\
0.30\end{array}$ & E & E \\
\hline II. 5 & 36 & $\mathrm{~F}$ & 0.86 & 0.38 & 0.36 & - & - \\
\hline $\begin{array}{l}\text { II. } 6 \\
\text { III. } 19\end{array}$ & $\begin{array}{r}1 \\
34\end{array}$ & $\begin{array}{l}M \\
M\end{array}$ & $\begin{array}{l}1.20 \\
0.65\end{array}$ & $\begin{array}{l}0.52 \\
0.35\end{array}$ & $\begin{array}{l}0.39 \\
0.34\end{array}$ & $\underline{x}$ & - \\
\hline
\end{tabular}


The mode of inheritance in this family is clearly dominant. Both the mode of inheritance and the absence of bilateral deafness in most cases show that this disease is different from the syndrome of Jervell and Lange-Nielsen which is an autosomal recessive disease. Dominantly inherited cases of the syndrome without deafness have also been described by Barlow, Bosman, and Craig Cochrane (1964), Romano (1965), and Garza et al (1970). Ours is the first report from The Netherlands.

We gratefully acknowledge the help of Dr E. H. Huizing, Department of Otorhinolaryngology of the University Hospital Leiden, for the audiometric testing of 19 members of the family.

\section{REFERENCES}

Barlow, J. B., Bosman, C. K., and Craig Cochrane, J. W. (1964). Congenital cardiac arrhythmia. Lancet, 2, 531.

Fraser, G. R., Froggatt, P., and James, T. N. (1964). Congenital deafness associated with electrocardiographic abnormalities, fainting attacks and sudden death. Quarterly fournal of Medicine, 33, 361-385.

Garza, L. A., Vick, R. L., Nora, J. J., and McNamara, D. G. (1970) Heritable QT-prolongation without deafness. Circulation, 41, 39-48.

Jervell, A. and Lange-Nielsen, F. (1957). Congenital deaf-mutism, functional heart disease, with prolongation of the QT-interval and sudden death. American Heart fournal, 54, 59-68.

Romano, C. (1965). Congenital cardiac arrhythmia. Lancet, 1, 658-659.

Ward, O. C. (1967). Familial cardiac arrhythmia. Bulletin of the Association of European Paediatric Cardiologists. 3, 33. 